\title{
KENDALA DALAM MENANGGULANGI TINDAK PIDANA PENIPUAN TRANSAKSI ELEKTRONIK DI INDONESIA
}

\author{
Hendy Sumadi \\ Fakultas Hukum Universitas Subang \\ E-mail: sumadihendy@gmail.com
}

\begin{abstract}
Birth of a law on information and electronic transactions, can not be removed from the spirit of the age that is global and demands the need for legal protection for users of information technology, which is seen as the group most vulnerable to crime one of them fraudulent electronic transactions. Almost eight years after the law was enacted, many cases of fraudulent use of electronic transactions continues to increase and tend spirit crime prevention by using electronic transactions are limited to legal texts written without any systematic effort to make a reality. Limitations of specialized tools owned by the cyber crime police districts in the regions up to the district level infrastructure to support investigators in uncovering the criminal fraud of electronic transactions is one of the obstacles in dealing with criminal fraud in an electronic transaction Indonesia.
\end{abstract}

Keywords: Fraudulent; Electronic Transactions.

\begin{abstract}
Abstrak
Lahirnya undang-undang tentang informasi dan transaksi elektronik, tidak dapat dilepas dari semangat zaman yang bersifat global serta tuntutan kebutuhan akan perlindungan hukum bagi pengguna teknologi informasi, yang dipandang sebagai kelompok yang paling rentan terhadap kejahatan salah satunya penipuan transaksi elektronik. Hampir delapan tahun setelah undang-undang ini diberlakukan, banyak kasus penipuan menggunakan transaksi elektronik terus meningkat dan cenderung semangat pencegahan kejahatan dengan menggunakan transaksi elektronik hanya terbatas pada teks hukum tertulis tanpa ada upaya yang sistematis untuk menjadikan suatu kenyataan. Keterbatasan alat-alat khusus cyber crime yang dimiliki oleh aparat kepolisian di daerahdaerah kabupaten sampai dengan tingkat kecamatan untuk menunjang sarana prasarana penyidik dalam mengungkap tindak pidana penipuan transaksi elektronik merupakan salah satu kendala dalam menanggulangi tindak pidana penipuan transaksi elektronik di Indonesia.
\end{abstract}

Kata Kunci: Penipuan, Transaksi Elektronik. 


\section{A. PENDAHULUAN}

Pesatnya perkembangan globalisasi teknologi informasi menjadikan sebuah fenomenakehidupanyangmenarik,dimana masyarakat pengguna teknologi informasi dalam berkomunikasi tidak lagi dibatasi oleh waktu dan tempat (borderless). Kapan pun dan dimana pun masyarakat pengguna perangkat teknologi tersebut bisa menjalin komunikasi, mendapatkan informasi, dan menyebarkan informasi kepada orang lain. Globalisasi teknologi tersebut menempatkan masyarakat Indonesia sebagai bagian dari masyarakat dunia pengguna teknologi komunikasi dan informasi. ${ }^{1}$ Globalisasi teknologi informasi juga telah merekayasa kehidupan masyarakat Indonesia ke era cyber dengan sarana internet yang menghadirkan cyberspace dengan realitas virtualnya menawarkan kepada masyarakat berbagai harapan dan kemudahan. Teknologi informasi dan komunikasi saat ini sedang mengarah kepada konvergensi yang memudahkan kegiatan manusia sebagai pencipta, pengembang dan pengguna teknologi itu sendiri. Salah satunya dapat dilihat dari perkembangan media internet yang sangat pesat. Internet sebagai suatu media dan komunikasi elektronik telah banyak di manfaatkan untuk berbagai kegiatan, antara lain untuk menjelajah (browsing,surfing), mencari berita, saling mengirim pesan melalui email, dan perdagangan. Kegiatan perdagangan dengan memanfaatkan media internet ini dikenal dengan istilah electronic commerce, atau disingkat e-commerce. ${ }^{2}$

Perkembangan teknologi informasi akan memberikan dampak yang sangat baik, bagi masyarakat perkembangan teknologi dapat membantu mobilitas karena aktifitas yang sangat padat, juga membawa kemudahan berinteraksi antara satu sama lain nyaris tanpa batas-batas negara dan wilayah. Berbagai kemudahan tersebut, diharapkan akan membawa masyarakat lebih maju, sejahtera dan mendatangkan kebaikan bagi kehidupan masyarakat Indonesia. Sebagaimana UUD 1945 Pasal 28F, menerangkan:

"Setiap orang berhak untuk
berkomunikasi dan memperoleh
informasi untuk mengembangkan
pribadidan lingkungan sosialnya, serta
berhak untuk mencari, memperoleh,
memiliki, menyimpan, mengolah, dan
menyampaikan informasi dengan
menggunakan segala jenis saluran
yang tersedia".

Kemajuan dibidang ilmu pengetahuan dan teknologi telekomunikasi dan informatika juga turut mendukung perluasan ruang gerak transaksi barang dan/atau jasa hingga melintasi batasbatas wilayah suatu negara. Teknologi informasi dan media elektronika dinilai sebagi simbol pelopor, yang akan mengintegrasikan seluruh sistem dunia, baik dalam aspek sosial budaya, ekonomi dan keuangan. Dari sistem-sistem kecil lokal dan nasional, proses globalisasi dalam tahun-tahun terakhir bergerak

\footnotetext{
$1 \quad$ Lihat konsiderans Undang-Undang Nomor 11 Tahun 2008 tentang Informasi dan Transaksi Elektronik.

2 Ahmad M Ramli, Cyber Law dan HAKI dalam Sistem Hukum Indonesia, Refika Aditama, Bandung, 2004, hlm. 1.
} 
cepat, bahkan terlalu cepat menuju suatu sistem global. $^{3}$

Proses globalisasi teknologi komunikasi dan informasi tersebut melahirkan suatu fenomena yang mengubah model komunikasi tradisional dan konvensional dengan melahirkan kenyataan dalam dunia maya (virtual reality) yang dikenal sekarang ini dengan internet. Internet berkembang demikian pesat sebagai kultur masyarakat modern, dikatakan sebagai kultur karena melalui internet berbagai aktifitas masyarakat cyber seperti berpikir, berkreasi, dan bertindak dapat diekspresikan di dalamnya, kapanpun dan dimanapun. Kehadirannya telah membentuk dunia tersendiri yang dikenal dengan dunia maya (cyberspace) atau dunia semu yaitu sebuah dunia komunikasi berbasis komputer yang menawarkan realitas yang baru berbentuk virtual (tidak langsung dan tidak nyata). ${ }^{4}$ Dunia virtual tidak mengenal dimensi waktu, ruang dan tempat, yang secara realitas menunjukkan hal yang tidak atau belum nyata.

Akan tetapi di balik itu, timbul persoalan berupa kejahatan yang dinamakan cybercrime, kejahatan ini juga tidak mengenal batas wilayah (borderless) serta waktu kejadian karena korban dan pelaku sering berada di negara yang berbeda. Barda Nawawi Arief mengemukakan cybercrime merupakan salah satu bentuk atau dimensi baru dari kejahatan masa kini yang mendapat perhatian masyarakat luas di dunia internasional, juga merupakan salah satu sisi gelap dari kemajuan teknologi yang mempunyai dampak negatif yang sangat luas bagi seluruh kehidupan modern saat ini. $^{5}$

Dampak negatif tersebut harus diantisipasi dan ditanggulangi dengan hukum yang terkait dengan pemanfaatan teknologi informasi dan komunikasi. Lahirnya Undang-Undang Nomor 11 tahun 2008 tentang Informasi dan Transaksi Elektronik, selanjutnya disebut Undang-Undang ITE, memang tidak dapat dilepaskan dari semangat zaman yang bersifat globalisasi tentang tuntutan perlunya perlindungan hukum bagi pengguna teknologi informasi, yang dipandang sebagai kelompok yang paling rentan terhadap tindak pidana salah satunya penipuan transaksi elektronik. Disahkannya Undang-Undang ITE tersebut, merupakan suatu pemikiran yang komprehensif dari Negara dengan political will untuk memperhatikan dan memberikan perlindungan hukum bagi pengguna teknologi informasi. Tentunya perlindungan hukum ini, tidak hanya kepada pengguna teknologi informasi yang digunakan secara positif, tetapi bagaimana undang-undang ini dapat mencegah dan mengungkap segala bentuk kejahatan salah satunya penipuan melalui transaksi elektronik.

3 Didik J Rachbini, Mitos dan Implikasi Globalisasi: Catatan Untuk Bidang Ekonomi dan Keuangan, Pengantar edisi Indonesia dalam Hirst, Paul dan Grahame Thompson, Globalisasi adalah Mitos, Yayasan Obor, Jakarta, 2001, hlm. 2.

4 Agus Rahardjo, Cybercrime Pemahaman dan Upaya Pencegahan Kejahatan Berteknologi, Citra Aditya Bakti, Bandung, 2002, hlm. 20.

5 Barda Nawawi Arief, Tindak Pidana Mayantara, Perkembangan Kajian Cybercrime di Indonesia, Raja Grafindo Persada, Jakarta, 2006, hlm. 26. 
Harapan pembentukan UndangUndang ITE, yang memuat delik pidana khusus terhadap setiap perbuatan melawan hukum yang berhubungan dengan perangkat teknologi informasi salah satunya adalah dapat menciptakan kebaikan, dari segala aktifitas yang membutuhkan perangkat teknologi informasi. Idealisme ini tentu bukan sesuatu yang berlebihan, di tengah kehidupan yang serba sangat maju, sebagai suatu kejanggalan, manakala lingkungan masyarakat yang seyogyanya dapat memberikan suasana yang memberikan kehidupan yang baik sepenuhnya ternyata sebaliknya menjadi lingkungan yang dipenuhi dengan unsur kejahatan. Dengan demikian keberhasilan penegakan hukum sebagaimana amanat dari Undang-Undang ITE ini, menjadi dambaan banyak pihak yang merindukan kenyamanan terhadap setiap aktifitas, yang membutuhkan teknologi informasi. Walaupun ternyata sampai dengan saat ini, 8 (delapan) tahun setelah UU ITE diterbitkan pada tahun 2008, harapan adanya keamanan dan kenyamanan dalam melakukan kegiatan transaksi elektronik ternyata tidak sesuai dengan kenyataan, tindak pidana penipuan transaksi elektronik menunjukkan peningkatan dari tahun ke tahun.

Perbuatan penipuan itu selalu ada bahkan cenderung meningkat dan berkembang di dalam masyarakat seiring kemajuan zaman, padahal perbuatan penipuan tersebut dipandang dari sudut manapun sangat tercela, karena dapat menimbulkan rasa saling tidak percaya dan akibatnya merusak tata kehidupan masyarakat. $^{6}$ Di dunia virtual orang melakukan berbagai kejahatan yang justru tidak dapat dilakukan di dunia maya. Kejahatan tersebut dilakukan dengan menggunakan komputer sebagai sarana perbuatannya, salah satu bentuk kejahatan tersebut adalah kejahatan penipuan dengan menggunakan transaksi elektronik. $^{7}$ Kejahatan cyber dengan modus email fraud (pelaku membajak email seseorang dan meminta untuk mengalihkan transfer ke rekening pelaku tanpa disadari) tercatat paling sering terjadi di Indonesia tahun 2015, meningkat dibanding tahun sebelumnya. Pada tahun 2012, kejahatan siber jenis penipuan melalui modus email fraud tercatat hanya 15 (lima belas) laporan. Tahun 2013, laporan meningkat menjadi 26 (dua puluh enam) laporan. Jumlah laporan kejahatan jenis ini lalu melonjak tajam pada tahun 2014 menjadi 111 (seratus sebilas) laporan. Adapun, tahun 2015 hingga bulan Oktober, laporan kembali melonjak tajam menjadi 208 (dua ratus delapan) laporan. ${ }^{8}$ Tindak pidana penipuan dengan menggunakan transaksi elektronik merupakan masalah yang sangat menarik untuk diteliti mengingat angka yang dilaporkan menunjukkan peningkatan dari tahun ke tahun.

6 Adami Chazawi, Tindak Pidana Informasi \& Transaksi Elektronik - Penyerangan Terhadap Kepentingan Hukum Pemanfaatan Teknologi ITE, Bayumedia Publishing, Malang, 2011, hlm. 1.

7 Sutan Remy Syahdeni, Kejahatan dan Tindak Pidana Komputer, Pustaka Utama Grafiti, Jakarta, 2006, hlm. 8.

8 Agung Setya, Awas!! Cyber Crime Modus Ini Paling Marak di Indonesia, http://www.jpnn.com/ $\mathrm{read} / 2015 / 12 / 20 / 345801 /$ awas!!-cyber-crime-modus-ini-paling-marak-di-Indonesia, diakses tanggal 15 Mei 2015, pukul 16.20 WIB. 
Indonesia sendiri berada di urutan kedua dalam daftar lima besar negara asal serangan kejahatan siber atau cyber crime, berdasar laporan State of The Internet 2013. Dalam kurun waktu tiga tahun terakhir, tercatat 36,6 juta serangan cyber crime terjadi di Indonesia. Hal ini sesuai dengan data Security Threat 2013 yang menyebutkan Indonesia adalah negara paling berisiko mengalami serangan cyber crime. Sejak 2012 sampai dengan April 2015, Subdit IT/ Cyber Crime telah menangkap 497 (empat ratus Sembilan puluh tujuh) orang tersangka kasus kejahatan di dunia maya. Dari jumlah tersebut, sebanyak 389 (tiga ratus delapan puluh sembilan) orang di antaranya merupakan warga negara asing, dan 108 orang merupakan warga negara Indonesia. Total kerugian cyber crime di Indonesia mencapai Rp 33,29 miliar, angka ini jauh lebih besar dibandingkan perampokan nasabah bank secara konvensional. ${ }^{9}$ Dalam kasus tindak pidana transaksi elektronik, modus yang sering dipakai terutama undian mendapatkan hadiah atau undian lewat internet, lewat iklan jual barang murah di toko online, kasus penipuan lewat rekening bank palsu dan lainnya. ${ }^{10}$

Kejahatan penipuan dengan menggunakan transaksi elektronik memiliki keunikan dan kekhasan karena kejahatan ini terjadi dalam ruang lingkup teknologi informasi. Modus penipuan melalui media internet dengan modus menawarkan barang-barang elektronik seperti handphone berbagai merk, kamera, laptop berbagai merk dengan harga murah di jejaring sosial facebook. Pelaku membuat akun facebook baru atau membobol akun facebook milik orang lain kemudian menambah pertemanan hingga ribuan orang. Kemudian pelaku menawarkan barang-barang elektronik dengan harga murah. Untuk meyakinkan korbannya, pelaku mengaku sebagai bagian marketing dan berusaha meyakinkan bahwa barang akan dikirim melalui jasa titipan kilat apabila Down Payment (DP) sudah dikirim ke rekening pelaku. Setelah DP dikirim, seolah-olah ada yang menelepon korban mengaku sebagai bagian pengiriman barang dan mengatakan bahwa barang sudah dikirim. Untuk meyakinkan korbannya, pelaku mengirimkan resi pengiriman. Keesokan harinya korban mendapat telepon mengaku bagian pengiriman dan menginformasikan bahwa telah terjadi kelebihan jumlah ítem yang dikirimkan dan mengharuskan korban untuk membayar saja kelebihan barang yang dikirimkan tersebut dengan imingiming diberikan diskon karena hal tersebut adalah kesalahan bagian pengiriman. Korban pun banyak yang tergiur dengan penawaran pelaku kemudian dengan

9 Agung Setya, Indonesia Urutan Kedua Terbesar Negara Asal Cyber Crime di Dunia, http://nasional. kompas.com/read/2015/05/12/06551741/Indonesia.urutan.kedua.terbesar.negara.asal.cyber.crime. di.dunia, diakses tanggal 15 Mei 2015, pukul 16.10 WIB.

10 Ririn NF, Kejahatan Sering Manfaatkan Transaksi Elektronik, http://www.pikiran-rakyat.com/ bandung-raya/2015/01/28/313911/kejahatan-sering-manfaatkan-transaksi-elektronik, diakses tanggal 30 Januari 2015, pukul 11:15 WIB. 
mudahnya mentransfer uang ke rekening pelaku. $^{11}$

Tindak pidana penipuan dengan menggunakan sarana transaksi elektronik merupakan suatu rintangan terhadap percepatan pembangunan ekonomi di Indonesia, karena kejahatan ini dapat menimbulkan akibat kumulatif yang tidak sederhana, salah satunya adalah beralihnya investasi perdagangan berbasis e commerce. Kebutuhan terhadap teknologi komunikasi dan informasi pada awalnya digunakan hanya untuk saling tukar informasi tetapi kemudian meningkat dari sekedar media komunikasi kemudian menjadi sarana untuk melakukan kegiatan komersil seperti informasi, promosi, penjualan dan pembelian produk. Terhadap adanya internet sendiri, di samping menciptakan berbagai peluang baru dalam kehidupan masyarakat, internet juga sekaligus menciptakan peluang-peluang baru bagi kejahatan.

Pemerintah Indonesia secara tertulis melalui teks perundang-undangan sudah memberikan upaya perlindungan hukum dan rasa aman terhadap segala perbuatan hukum yang berhubungan dengan teknologi informasi termasuk transaksi elektronik, yaitu dengan diakomodasinya hak untuk berkomunikasi dan memperoleh informasi untuk mengembangkan pribadi dan lingkungan sosialnya, serta berhak untuk mencari, memperoleh, memiliki, menyimpan, mengolah, dan menyampaikan informasi dengan menggunakan segala jenis saluran yang tersedia. Tetapi, setelah hampir delapan tahun undang-undang ini diberlakukan, berbagai kasus penipuan dengan menggunakan transaksi elektronik tetap meningkat dan cenderung semangat pencegahan terhadap kejahatan dengan menggunakan transaksi elektronik hanya ada sebatas teks tertulis dalam undangundang tanpa disertai upaya konkret dan sistematis untuk mewujudkannya. Penipuan dengan menggunakan transaksi elektronik merupakan masalah bersama, olehkarenaitumasyarakatjugapemerintah turut bertanggung jawab dengan melakukan pencegahan dari segala bentuk kejahatan yang menggunakan transaksi elektronik. Sehingga ada perubahan sikap yang mendasar dalam kehidupan bermasyarakat yang menganggap bahwa tindak pidana penipuan dengan menggunakan transaksi elektronik bukan sekedar masalah individu tetapi merupakan tanggung jawab bersama.

\section{B. PEMBAHASAN}

1. Perlindungan Hukum bagi Masyarakat Pengguna Transaksi Elektronik.

Kebutuhan masyarakat terhadap rasa aman dan terlindungi merupakan salah satu hak asasi yang harus diperoleh atau dinikmati setiap orang. Rasa aman dan terlindungi juga merupakan kebutuhan dasar masyarakat yang sangat penting, setelah kebutuhan akan sandang, pangan dan papan. Hak atas rasa aman dan terlindungi masyarakat tersebut, tertuang

11 Hermawan, Subdit IV Cyber Crime Ungkap Penipuan Melalui Jejaring Sosial Facebook, http://www. reskrimsus.metro.polri.go.id/info/berita/SUBDIT-IV-cyber-crime-ungkap-penipuan-melalui-jejaringsosial-facebook, diakses tanggal 30 Januari 2015, pukul 12:15 WIB. 
dalam UUD 1945 Pasal 28G ayat (1) yang menerangkan:

"Setiap orang berhak atas perlindungan diri pribadi, keluarga, kehormatan, martabat, dan harta benda yang di bawah kekuasaannya, serta berhak atas rasa aman dan perlindungan dari ancaman ketakutan untuk berbuat atau tidak berbuat sesuatu yang merupakan hak asasi”.

Undang-undang Dasar Negara Republik Indonesia Tahun 1945 (selanjutnya disingkat UUD 1945) sebagai landasan konstitusional yang di dalamnya dijiwai oleh Pancasila, merupakan arah politik dari hukum nasional yang dimuat dalam Alinea Keempat Pembukaan Undang-undang Dasar Negara Republik Indonesia Tahun 1945, sebagai berikut:

... untuk membentuk suatu pemerintahan negara Indonesia yang melindungi segenap bangsa Indonesia dan seluruh tumpah darah Indonesia dan untuk memajukan kesejahteran umum, mencerdaskan kehidupan bangsa, dan ikut melaksanakan ketertiban dunia yang berdasarkan kemerdekaan, perdamaian abadi dan keadilan sosial ...
Pasal 1 ayat (3) UUD 1945, menyatakan bahwa: Negara Indonesia adalah negara hukum. Ketentuan tersebut merupakan landasan bagi arah politik hukum dalam pembangunan hukum nasional negara untuk selalu memberikan pelayanan publik, $^{12}$ sehingga sampai saat ini orang bertumpu pada kata segenap bangsa sebagai asas tentang persatuan seluruh bangsa Indonesia. ${ }^{13}$ Disamping itu, kata melindungi mengandung asas perlindungan hukum pada segenap bangsa Indonesia, tanpa kecuali. ${ }^{14}$ Artinya negara turut campur dan bertanggung jawab ${ }^{15}$ dalam upaya mengangkat harkat dan martabat manusia sebagai perwujudan perlindungan hukum. ${ }^{16}$ Pasal ini dapat dikorelasikan dengan pasal-pasal yang mengatur tentang kejahatan penipuan dengan menggunakan transaksi elektronik.

Menurut teori atau paham negara hukum(rechtstaat), negaraharusmenjamin persamaan setiap warga negara termasuk kemerdekaan menggunakan hak asasinya. Atas dasar itu, negara hukum tidak boleh bertindak sewenang-wenang terhadap warga negaranya dan kekuasaannya harus dibatasi, ${ }^{17}$ demikian pula warga negara dibatasi dalam penggunaan hak asasinya dengan hukum sebagai sarananya. ${ }^{18}$ Oleh karena itu, dalam suatu negara hukum kedudukan dan hubungan warga negara

\footnotetext{
12 Ni'matul Huda, Negara Hukum, Demokrasi \& Judicial Review, UII Press, Yogyakarta, 2005, hlm. 8. Lihat Hotma P. Sibuea, Asas Negara Hukum, Peraturan Kebijakan \& Asas-asas Umum Pemerintahan yang Baik, Erlangga, Jakarta, 2010, hlm. 37.

13 Az. Nasution, Hukum Perlindungan Konsumen (Suatu Pengantar), Diadit Media, Jakarta, 2002, hlm. 31.

14 Idem.

15 Wagiati Soetedjo, Hukum Pidana Anak, Refika Aditama, Bandung, 2008, hlm. 68.

16 M. Arief Amarullah, Politik Hukum Pidana dalam Perlindungan Korban Kejahatan Ekonomi di Bidang Perbankan, Banyumedia, Malang, 2007, hlm. 2.

17 Satjipto Rahardjo, Membedah Hukum Progresif, Kompas, Jakarta, 2007, hlm. 240. Lihat A. Mukhtie Fadjar, Tipe Negara Hukum, Banyumedia, Malang, 2005, hlm. 84.

18 Padmo Wahjono, Indonesia Negara Berdasarkan atas Hukum, Ghalia Indonesia, Jakarta, 1986, hlm. 160.
} 
dengan negara adalah dalam suasana keseimbangan, sama-sama mempunyai hak yang dilindungi oleh hukum dan samasama dibatasi oleh hukum. ${ }^{19}$

Sementara itu, menurut Mochtar Kusumaatmadja, bahwa tujuan hukum tersebut pada akhirnya diarahkan untuk memberikan perlindungan kepada kepentingan manusia, yaitu kepentingan dalam melangsungkan dan memenuhi kebutuhan hidup yang layak tanpa diskriminasi. ${ }^{20}$ Oleh karenanya, hukum bukan hanya sekedar keseluruhan asasasas dan kaidah-kaidah yang mengatur kehidupan manusia dalam masyarakatyang meliputi lembaga-lembaga (institutions) dan proses-proses (process), tetapi melalui hukum ini hendak diwujudkan berlakunya tujuan hukum menjadi kenyataan. ${ }^{21}$

Hukum bukan tujuan, tetapi dibuat sebagai sarana mencapai tujuan hukum yang dapat digerakkan untuk merekayasa umat manusia menuju tujuan yang baik dan benar serta diridhai Allah SWT ${ }^{22}$ atau dalam istilah Roscoe Pound adalah law as a tool of social engineering (hukum sebagai alat pembaharuan masyarakat) atau dengan perkataan lain, sebagaimana dikemukakan Mochtar Kusumaatmadja, bahwa hukum merupakan sarana pembangunan (a tool of development), yakni hukum dalam arti kaidah atau peraturan hukum yang difungsikan sebagai alat (pengatur) atau sarana yang mengatur pembangunan dalam penyalur arah kegiatan manusia ke arah yang dikehendaki oleh pembangunan atau pembaruan. $^{23}$

Demokrasi sebagai suatu sistem politik dalam negara hukum memuat atau mengandung esensi persamaan (equity) dan kebebasan (liberty) warga negara. Warga negara adalah pemilik kedaulatan, oleh karena itu hak-hak warga negara yang menjelma sebagai hak asasi harus terjamin keberadaan dan implementasinya dalam negara. ${ }^{24}$ Begitu juga bagi masyarakat pengguna transaksi elektronik tentunya mempunyai hak yang sama untuk mendapatkan perlindungan hukum dalam menjalankan segala perbuatan hukum melalui sarana teknologi informasi. Suatu negara yang berdasarkan atas hukum harus menjamin

19 Konsekuensi, bahwa Indonesia negara berdasarkan hukum (rechtsstaat) tidak berdasarkan atas kekuasaan belaka (machtstaat) dan pemerintahan berdasarkan sistem konstitusi (hukum dasar) bukan absolutisme (kekuasaan yang tidak terbatas) dengan prinsip dasar yang wajib dijunjung tinggi oleh setiap warga negara adalah supremasi hukum, kesetaraan di hadapan hukum, dan penegakan hukum dengan cara-cara yang tidak bertentangan dengan hukum. Lihat Ujang Charda S., "Reaktualisasi Supremasi Hukum dalam Merekonstruksi Lembaga Peradilan Menuju Indonesia Baru”, Jurnal Jurista Insentif'06, Vol. 1 No. 1, Kopertis Wilayah IV Jabar - Banten, Bandung, 2006, hlm. 48-49.

20 Mochtar Kusumaatmadja, Fungsi dan Perkembangan Hukum dalam Pembangunan Nasional, Binacipta, Bandung, Tanpa Tahun, hlm. 3.

21 Mochtar Kusumaatmadja, Hukum, Masyarakat dan Pembinaan Hukum Nasional, Binacipta, Bandung, 1976, hlm. 15.

22 Juhaya S. Praja, Filsafat Hukum Islam, Lathifah Press bekerjasama dengan Fakultas Syari'ah IAILM Suryalaya, Tasikmalaya, 2004, hlm. 75.

23 Mochtar Kusumaatmadja, Konsep-konsep Hukum dalam Pembangunan, Alumni, Bandung, 2002, hlm. 88.

24 Edi Suharto, Kebijakan Sosial sebagai Kebijakan Publik : Peranan Pembangunan Kesejahteraan Sosial dan Pekerjaan Sosial dalam Mewujudkan Negara Kesejahteraan (Welfare State) di Indonesia, Alfabeta, Bandung, 2008, hlm. 58. 
persamaan (equality) setiap individu, termasuk kemerdekaan individu untuk menggunakan hak asasinya.

Pada dasarnya setiap manusia terlahir sebagai makhluk ciptaan ALLAH SWT, yang secara kodrati mendapatkan hak dasar yaitu kebebasan, hak hidup, hak untuk dilindungi dan hak lainnya. Hal ini senada dengan prinsip hukum alam pada abad ke-18 yaitu kebebasan individu dan keutamaan rasio, salah satu penganutnya adalah Locke, menurut Locke teori hukum beranjak dari kebebasan individu dan keutamaan rasio. Locke juga mengajarkan pada kontrak sosial, menurutnya yang melakukan kontrak sosial adalah manusia yang tertib dan menghargai kebebasan, hak hidup dan pemilikan harta sebagai hak bawaan manusia. ${ }^{25}$

Menurut Locke, hak-hak tersebut tidak diserahkan kepada penguasa ketika kontrak sosial dilakukan. Oleh karena itu, kekuasaan penguasa yang diberikan lewat kontrak sosial dengan sendirinya tidak mungkin bersifat mutlak, dengan begitu kekuasaan tersebut justru untuk melindungi hak-hak kodrat dimaksud dari bahaya-bahaya yang mungkin mengancam, baik datang dari dalam maupun dari luar. Begitu juga hukum yang dibuat dalam Negara, bertugas melindungi hak-hak dasar tersebut. Hak-hak dasar yang biasa disebut sebagai hak asasi, tanpa perbedaan antara satu dengan lainnya. Dengan hak asasi manusia dapat mengembangkan diri pribadi, peranan dan sumbangannya bagi kesejahteraan hidup manusia. ${ }^{26}$
Prinsip perlindungan hukum terhadap tindakan pemerintah bertumpu dan bersumber dari konsep tentang pengakuan dan perlindungan terhadap hak-hak asasi manusia, karena menurut sejarah dari barat lahirnya konsep-konsep tentang pengakuan dan perlindungan terhadap hak-hak asasi manusia diarahkan kepada pembatasan-pembatasan dan peletakkan kewajiban masyakat dan pemerintah. Aspek dominan dalam konsep barat tentang hak asasi manusia menekankan eksistensi hak dan kebebasan yang melekat pada kodrat manusia dan statusnya sebagai individu, hak tersebut berasa di atas negara dan di atas semua organisasi politik dan bersifat mutlak sehingga tidak dapat diganggu gugat. Terhadap konsep ini, terdapat beberapa kritik bahwa konsep barat tentang hak-hak asasi manusia adalah konsep individualistik. Kemudian dengan masuknya hak-hak sosial dan hakhak ekonomi serta hak kultural, terdapat kecenderungan mulai melenturnya sifat individualistik dari konsep barat.

Prinsip-prinsip perlindungan hukum di Indonesia, landasannya adalah Pancasila sebagai ideologi dan falsafah negara. Konsepsi perlindungan hukum bagi rakyat di barat bersumber pada konsep-konsep Rechstaat dan Rule of The Law. Menggunakan konsepsi barat sebagai kerangka berpikir, dengan landasan Pancasila pada Pancasila. Prinsip perlindungan hukum di Indonesia adalah prinsip pengakuan dan perlindungan terhadap harkat dan martabat manusia

\footnotetext{
25 Raypratama, Perlindungan Hukum, blogspot.com/2015/04/teori-perlindungan-hukum.html, diakses tanggal 19 Juni 2015, pukul 15.00.WIB.

26 Idem.
} 
yang bersumber pada Pancasila. Prinsip perlindungan hukum terhadap tindak pemerintah bertumpu dan bersumber dari konsep tentang pengakuan dan perlindungan terhadap hak-hak asasi manusia karena menurut sejarahnya di Barat, lahirnya konsep-konsep tentang pengakuan dan perlindungan terhadap hak-hak asasi manusia diarahkan kepada pembatasan-pembatasan dan peletakkan kewajiban masyarakat dan pemerintah. ${ }^{27}$

Perlindungan hukum merupakan suatu hal yang melindungi subyek-subyek hukum melalui peraturan perundangundangan yang berlaku dan dipaksakan pelaksanaannya dengan suatu sanksi. Perlindungan hukum dapat dibedakan menjadi dua, yaitu: ${ }^{28}$

a. Perlindungan hukum preventif, merupakan perlindungan yang diberikan oleh Pemerintah dengan tujuan mencegah sebelum terjadinya pelanggaran. Hal ini terdapat dalam peraturan perundang-undangan dengan maksud untuk mencegah suatu pelanggaran serta memberikan rambu-rambu atau batasan-batasan dalam melakukan suatu kewajiban.

b. Perlindungan hukum represif, merupakan perlindungan akhir berupa sanksi seperti denda, penjara dan hukuman tambahan yang diberikan apabila sudah terjadi sengketa atau telah dilakukan suatu pelanggaran.
Lebih lanjut Setiono, bahwa perlindungan hukum adalah tindakan atau upaya untuk melindungi masyarakat dari perbuatan sewenang-wenang oleh penguasa yang tidak sesuai dengan aturan hukum, untuk mewujudkan ketertiban dan ketentraman sehingga memungkinkan manusia untuk menikmati martabatnya sebagai manusia. Menurut Muchsin, perlindungan hukum merupakan kegiatan untuk melindungi individu dengan menyerasikan hubungan nilai-nilai atau kaidah-kaidah yang menjelma dalam sikap dan tindakan dalam menciptakan adanya ketertiban dalam pergaulan hidup antar sesama manusia. ${ }^{29}$

Soetjipto Rahardjo mengemukakan bahwa perlindungan hukum adalah adanya upaya melindungi kepentingan seseorang dengan cara mengalokasikan suatu kekuasaan kepadanya untuk bertindak dalam kepentingannya tersebut. Selanjutnya dikemukakan pula bahwa salah satu sifat dan sekaligus merupakan tujuan dari hukum adalah memberikan perlindungan (pengayoman) kepada masyarakat. Oleh karena itu, perlindungan hukum terhadap masyarakat tersebut harus diwujudkan dalam bentuk adanya kepastian hukum. ${ }^{30}$ Menurut Sutarman dalam menjamin keamanan, keadilan dan kepastian hukum dalam penegakan hukum (law enforcement) di dunia cyber dapat terlaksana dengan baik, maka harus dipenuhi 4 (empat) syarat yaitu: ${ }^{31}$

27 Philipus M. Hadjon, Perlindungan Hukum Bagi Rakyat Indonesia, Bina Ilmu, Surabaya, 1987, hlm. 38.

28 Ibid., hlm. 60.

29 Muchsin, Perlindungan dan Kepastian Hukum bagi Investor di Indonesia, Magister Ilmu Hukum Program Pascasarjana, Surakarta, 2003, hlm. 14.

30 Satjipto Rahardjo, Permasalahan Hukum di Indonesia, Alumni, Bandung, 1983, hlm. 121.

31 Sutarman, Cybercrime: Modus Operandi dan Penanggulangannya, Laksbang Pressindo, Jogjakarta, 2007, hlm.108-109. 
a. Adanya aturan perundang-undangan khusus yang mengatur dunia cyber.

b. Adanya lembaga yang akan menjalankan peraturan yaitu polisi, jaksa dan hakim khusus menangani cybercrime.

c. Adanya fasilitas atau sarana untuk mendukung pelaksanaan peraturan itu.

d. Kesadaran hukum dari masyarakat yang terkena peraturan.

Pemerintah Indonesia saat ini, secara tertulis melalui teks perundangundangan sudah memberikan upaya perlindungan hukum dan rasa aman terhadap segala perbuatan hukum dalam bentuk transaksi elektronik, yaitu salah satunya dengan diterbitkannya UndangUndang Nomor 11 Tahun 2008 tentang Informasi dan Transaksi Elektronik. Tetapi tentunya perlindungan hukum dan upaya memberikan rasa aman tersebut harus diwujudkan dalam bentuk adanya kepastian hukum, sehingga terciptanya masyarakat yang penuh dengan kebaikan dan adanya rasa terlindungi bagi seluruh masyarakat pada umumnya, khususnya masyarakatpengguna transaksi elektronik.

\section{Kebijakan Formulasi Pengaturan Tindak Pidana Teknologi Informasi Menurut UU ITE.}

Kebijakan kriminalisasi merupakan suatu kebijakan dalam menetapkan suatu perbuatan yang semula bukan tindak pidana (tidak dipidana) menjadi suatu tindak pidana (perbuatan yang dapat dipidana). Jadi pada hakekatnya, kebijakan kriminalisasi merupakan bagian dari kebijakan kriminal (criminal policy) dengan menggunakan sarana hukum pidana (penal), dan oleh karena itu termasuk bagian dari kebijakan hukum pidana (penal policy), khususnya kebijakan formulasinya. ${ }^{32}$

Kebijakan pemerintah Indonesia dengan diundangkannya UU ITE merupakan payung hukum pertama yang mengatur dunia siber (cyberlaw), sebab muatan dan cakupannya yang luas dalam membahas pengaturan di dunia maya seperti perluasan alat bukti elektronik sama dengan alat bukti yang sudah dikenal selama ini, diakuinya tanda tangan elektronik sebagai alat verifikasi, dan autentikasi yang sah suatu dokumen elektronik, serta pengaturan perbuatanperbuatan yang dilakukan dalam cyberspace sebagai suatu tindak pidana. Kebijakan formulasi pengaturan tindak pidana teknologi informasi di Indonesia diatur UU ITE yang bersifat khusus (lex specialist). Kebijakan hukum tersebut tertuang dalam UU ITE Pasal 45 sampai dengan Pasal 52 juncto Pasal 27 sampai dengan Pasal 37. Isi dari Pasal 27 sampai dengan Pasal 37 UU ITE, diuraikan sebagai berikut:

\section{Pasal 27:}

(1) Setiap Orang dengan sengaja dan tanpa hak mendistribusikan dan/atau mentransmisikan dan/atau membuat dapat diaksesnya Informasi Elektronik

32 Barda Nawawi Arief, Pembaharuan Hukum Pidana Dalam Perspektif Kajian Perbandingan, Citra Aditya Bakti, Bandung, 2005, hlm. 126. Lihat juga dalam Barda Nawawi Arief, Tindak Pidana Mayantara, Perkembangan Kajian Cybercrime di Indonesia, RajaGrafindo Persada, Jakarta, 2006, hlm. 90. Lihat juga pengertian kriminalisasi oleh Sudarto, Hukum dan Hukum Pidana, Alumni, Bandung, 1977, hlm. 32. 
dan/atau Dokumen Elektronik yang memiliki muatan yang melanggar kesusilaan.

(2) Setiap Orang dengan sengaja dan tanpa hak mendistribusikan dan/atau mentransmisikan dan/atau membuat dapat diaksesnya Informasi Elektronik dan/atau Dokumen Elektronik yang memiliki muatan perjudian.

(3) Setiap Orang dengan sengaja dan tanpa hak mendistribusikan dan/atau mentransmisikan dan/atau membuat dapat diaksesnya Informasi Elektronik dan/atau Dokumen Elektronik yang memiliki muatan penghinaan dan/ atau pencemaran nama baik.

(4) Setiap Orang dengan sengaja dan tanpa hak mendistribusikan dan/atau mentransmisikan dan/atau membuat dapat diaksesnya Informasi Elektronik dan/atau Dokumen Elektronik yang memiliki muatan pemerasan dan/atau pengancaman.

\section{Pasal 28:}

(1) Setiap Orang dengan sengaja dan tanpa hak menyebarkan berita bohong dan

(2) Menyesatkan yang mengakibatkan kerugian konsumen dalam Transaksi Elektronik.

(3) Setiap Orang dengan sengaja dan tanpa hak menyebarkan informasi yang ditujukan untuk menimbulkan rasa kebencian atau permusuhan individu dan/atau kelompok masyarakat tertentu berdasarkan atas suku, agama, ras, dan antargolongan (SARA).

\section{Pasal 29:}

Setiap Orang dengan sengaja dan tanpa hak mengirimkan Informasi Elektronik dan/atau Dokumen Elektronik yang berisi ancaman kekerasan atau menakut-nakuti yang ditujukan secara pribadi.

\section{Pasal 30}

(1) Setiap Orang dengan sengaja dan tanpa hak atau melawan hukum mengakses Komputer dan/atau Sistem Elektronik milik Orang lain dengan cara apa pun.

(2) Setiap Orang dengan sengaja dan tanpa hak atau melawan hukum mengakses Komputer dan/atau Sistem Elektronik dengan cara apa pun dengan tujuan untuk memperoleh Informasi Elektronik dan/atau Dokumen Elektronik.

(3) Setiap Orang dengan sengaja dan tanpa hak atau melawan hukum mengakses Komputer dan/atau Sistem Elektronik dengan cara apa pun dengan melanggar, menerobos, melampaui, atau menjebol sistem pengamanan.

\section{Pasal 31:}

(1) Setiap Orang dengan sengaja dan tanpa hak atau melawan hukum melakukan intersepsi atau penyadapan atas Informasi Elektronik dan/atau Dokumen Elektronik dalam suatu Komputer dan/atau Sistem Elektronik tertentu milik Orang lain.

(2) Setiap Orang dengan sengaja dan tanpa hak atau melawan hukum melakukan intersepsi atau transmisi Informasi Elektronik dan/atau Dokumen Elektronik yang tidak bersifat publik dari, ke, dan di dalam suatu Komputer dan/atau Sistem Elektronik tertentu 
milik Orang lain, baik yang tidak menyebabkan perubahan apa pun maupun yang menyebabkan adanya perubahan, penghilangan, dan/atau penghentian Informasi Elektronik dan/atau Dokumen Elektronik yang sedang ditransmisikan.

(3) Kecuali intersepsi sebagaimana dimaksud pada ayat (1) dan ayat (2), intersepsi yang dilakukan dalam rangka penegakan hukum atas permintaan kepolisian, kejaksaan, dan/atau institusi penegak hukum lainnya yang ditetapkan berdasarkan undang_undang.

(4) Ketentuan lebih lanjut mengenai tata cara intersepsi sebagaimana dimaksud pada ayat (3) diatur dengan Peraturan Pemerintah.

\section{Pasal 32:}

(1) Setiap Orang dengan sengaja dan tanpa hak atau melawan hukum dengan cara apapun mengubah, menambah, mengurangi, melakukan transmisi, merusak, menghilangkan, memindahkan, menyembunyikan suatu Informasi Elektronik dan/atau Dokumen Elektronik milik Orang lain atau milik publik.

(2) Setiap Orang dengan sengaja dan tanpa hak atau melawan hukum dengan cara apa pun memindahkan atau mentransfer Informasi Elektronik dan/atau Dokumen Elektronik kepada Sistem Elektronik Orang lain yang tidak berhak.

(3) Terhadap perbuatan sebagaimana dimaksud pada ayat (1) yang mengakibatkan terbukanya suatu Informasi Elektronik dan/atau
Dokumen Elektronik yang bersifat rahasia menjadi dapat diakses oleh publik dengan keutuhan data yang tidak sebagaimana mestinya.

\section{Pasal 33}

Setiap Orang dengan sengaja dan tanpa hak atau melawan hukum melakukan tindakan apa pun yang berakibat terganggunya Sistem Elektronik dan/atau mengakibatkan Sistem Elektronik menjadi tidak bekerja sebagaimana mestinya.

\section{Pasal 34}

(1) Setiap Orang dengan sengaja dan tanpa hak atau melawan hukum memproduksi, menjual, mengadakan untuk digunakan, mengimpor, mendistribusikan, menyediakan, atau memiliki:

a. perangkat keras atau perangkat lunak Komputer yang dirancang atau secara khusus dikembangkan untuk memfasilitasi perbuatan sebagaimana dimaksud dalam Pasal 27 sampai dengan Pasal 33;

b. sandi lewat Komputer, Kode Akses, atau hal yang sejenis dengan itu yang ditujukan agar Sistem Elektronik menjadi dapat diakses dengan tujuan memfasilitasi perbuatan sebagaimana dimaksud dalam Pasal 27 sampai dengan Pasal 33.

(2) Tindakan sebagaimana dimaksud pada ayat (1) bukan tindak pidana jika ditujukan untuk melakukan kegiatan penelitian, pengujian Sistem Elektronik, untuk perlindungan Sistem Elektronik itu sendiri secara sah dan tidak melawan hukum. 


\section{Pasal 35}

Setiap Orang dengan sengaja dan tanpa hak atau melawan hukum melakukan manipulasi, penciptaan, perubahan, penghilangan, pengrusakan Informasi Elektronik dan/atau Dokumen Elektronik dengan tujuan agar Informasi Elektronik dan/atau Dokumen Elektronik tersebut dianggap seolah-olah data yang otentik.

\section{Pasal 36}

Setiap Orang dengan sengaja dan tanpa hak atau melawan hukum melakukan perbuatan sebagaimana dimaksud dalam Pasal 27 sampai dengan Pasal 34 yang mengakibatkan kerugian bagi Orang lain.

\section{Pasal 37}

Setiap Orang dengan sengaja melakukan perbuatan yang dilarang sebagaimana dimaksud dalam Pasal 27 sampai dengan Pasal 36 di luar wilayah Indonesia terhadap Sistem Elektronik yang berada di wilayah yurisdiksi Indonesia.

Perbuatan-perbuatan di atas sangat berhubungan dengan pemanfaatan teknologi yang berkenaan dengan informasi, sistem informasi (information system), serta sistem komunikasi yang merupakan sarana untuk penyampaian/ pertukaran informasi itu kepada pihak lainnya (transmitter/orginator to recipient). ${ }^{33}$ Secara garis besar tindak pidana teknologi informasi terdiri dari dua jenis, yaitu: Kejahatan yang menggunakan teknologi informasi (TI) sebagai fasilitas dan kejahatan yang menjadikan sistem dan fasilitas teknologi informasi (TI) sebagai sasaran. Cybercrime dirumuskan sebagai perbuatan melawan hukum yang dilakukan dengan memakai jaringan komputer sebagai sarana/alat atau komputer sebagai objek, baik untuk memperoleh keuntungan ataupun tidak, dengan merugikan pihak lain.

Pendapat tersebut sejalan dengan Tenth United Nations congress on the Prevention of Crime and the Traitment of Offender di Vienna pada 10-17 April 2000, membagi 2 (dua) subkategori cybercrime, yaitu: ${ }^{34}$

a. Cybercrime in a narrow sense (dalam arti sempit) disebut computer crime: any illegal behavior directed by means of electronic operation that target the security of computer system and the data processed by them.

b. Cybercrime in a broader sense (dalam arti luas) disebut computer related crime: any illegal behavior committed by means on relation to, a computer system offering or system or network, including such crime as illegal possession in, offering or distributing information by means of computer system or network.

Kebijakan kriminalisasi dalam UU ITE tercantum dalam Bab XI tentang Ketentuan Pidana (Pasal 45 sampai dengan Pasal 52) juncto Pasal 27 sampai dengan Pasal

33 Wigantoro Roes Setiyadi, Naskah akademik RUU tindak pidana di bidang Teknologi Informasi, CyberPolicy Club dan Indonesia Media Law and Policy Center, 2003, hlm. 25.

34 Tenth United Nations congress on the Prevention of Crime and the Traitment of Offender, sebagaimana dikutip: Agus Raharjo, Cybercrime Pemahaman dan Upaya Pencegahan Kejahatan Berteknologi, Citra Aditya Bakti, Bandung, 2002, hlm. 229. 
36, dapat terlihat dalam tabel 1 (satu) di

bawah ini:

Tabel Pembagian Kriminalisasi dalam UU ITE

\begin{tabular}{|l|l|l|l|}
\hline \multicolumn{2}{|c|}{$\begin{array}{l}\text { Teknologi Informasi } \\
\text { sebagai Fasilitas }\end{array}$} & \multicolumn{1}{c|}{$\begin{array}{l}\text { Teknologi Informasi } \\
\text { sebagai Objek }\end{array}$} \\
\hline \multicolumn{1}{|c|}{ Pasal } & \multicolumn{1}{|c|}{ Muatan } & \multicolumn{1}{c|}{ Pasal } & \multicolumn{1}{c|}{ Muatan } \\
\hline $\begin{array}{l}\text { Ps 45 jo } \\
\text { Ps 27 }\end{array}$ & $\begin{array}{l}\text { Pelanggaran } \\
\text { asusila, perjudian, } \\
\text { penghinaan atau } \\
\text { pencemaran nama } \\
\text { baik. }\end{array}$ & $\begin{array}{l}\text { Ps 46 } \\
\text { jo Ps 30 }\end{array}$ & $\begin{array}{l}\text { Mengakses sistem } \\
\text { orang lain. }\end{array}$ \\
\hline $\begin{array}{l}\text { Ps 45 ayat (2) } \\
\text { jo Ps 28 }\end{array}$ & $\begin{array}{l}\text { Penipuan, } \\
\text { menyebarkan } \\
\text { informasi yang } \\
\text { menyesatkan. }\end{array}$ & Js 47 & $\begin{array}{l}\text { Melakukan intersepsi } \\
\text { atau penyadapan } \\
\text { (illegal interception) }\end{array}$ \\
\hline $\begin{array}{l}\text { Ps 45 ayat (3) } \\
\text { jo Ps 29 }\end{array}$ & $\begin{array}{l}\text { Pengancaman } \\
\text { kekerasan }\end{array}$ & $\begin{array}{l}\text { Ps 48 } \\
\text { jo Ps 32 }\end{array}$ & $\begin{array}{l}\text { Perbuatan melawan } \\
\text { hukum terhadap } \\
\text { sistem/dokumen } \\
\text { elektronik (data } \\
\text { interference) }\end{array}$ \\
\hline $\begin{array}{l}\text { Ps 51 ayat (1) } \\
\text { jo Ps 35 }\end{array}$ & $\begin{array}{l}\text { Pemalsuan } \\
\text { informasi/dokumen } \\
\text { elektronik }\end{array}$ & $\begin{array}{l}\text { Ps 49 } \\
\text { jo Ps 33 }\end{array}$ & $\begin{array}{l}\text { Terganggunya sistem } \\
\text { komputer }\end{array}$ \\
\cline { 2 - 4 } & $\begin{array}{l}\text { Ps 50 } \\
\text { jo Ps 34 }\end{array}$ & $\begin{array}{l}\text { Penyalahgunaan } \\
\text { komputer }\end{array}$ \\
\hline
\end{tabular}

Kebijakan kriminalisasi dalam UU ITE sebagaimana terlihat dalam tabel 1 (satu) di atas perlu diperhatikan hal-hal yang intinya sebagai berikut: ${ }^{35}$

a. Penggunaan hukum pidana harus memperhatikan tujuan pembangunan nasional, yaitu mewujudkan masyarakat adil makmur yang merata materiil dan spiritual berdasarkan Pancasila;

b. sehubungan dengan ini (penggunaan) hukum pidana bertujuan untuk menanggulangi kejahatan dan mengadakan pengugeran terhadap tindakan penanggulangan itu sendiri, demi kesejahteraan dan pengayoman masyarakat.

c. Perbuatan yang diusahakan untuk dicegah atau ditanggulangi dengan hukum pidana harus merupakan perbuatan yang tidak dikehendaki yaitu perbuatan yang mendatangkan kerugian (materil dan spirituil) atas warga masyarakat.

d. Penggunaan hukum pidana harus pula memperhitungkan prinsip biaya dan hasil (cost dan benefit principle)

35 Sudarto, Hukum dan Hukum Pidana ..., Op.Cit., hlm. 23. 
e. Penggunaan hukum pidana harus pula memperhatikan kapasitas atau kemampuan daya kerja dari badanbadan penegak hukum yaitu jaringan sampai ada kelampauan beban tugas (overblasting).

Lokakarya yang diorganisir oleh UNAFEI selama kongres PBB X/2000 berlangsung telah memberikan pedoman dalam melakukan kriminalisasi terhadap kejahatan yang berhubungan dengan jaringan komputer, yaitu: ${ }^{36}$

a. Computer Related Crime (CRC) harus dikriminalisasikan;

b. Diperlukan hukum acara yang tepat untuk melakukan penyidikan dan penuntutan terhadap penjahat cyber (cyber criminals);

c. Harus ada kerja sama antara pemerintah dan industri terhadap tujuan umum pencegahan dan penanggulangan kejahatan komputer agar internet menjadi tempat yang aman;

d. Diperlukan kerja sama internasional untuk menelusuri/mencari penjahat di internet;

e. PBB harus mengambil langkah/tindak lanjut yang berhubungan dengan bantuan kerja sama teknis dalam penanggulangan CRC.

Kebijakan kriminalisasi bukan sekedar kebijakan menetapkan/merumuskan/ memformulasikan perbuatan apa yang dapat dipidana (termasuk sanksi pidananya), melainkan juga mencakup masalah bagaimana kebijakan formulasi/ legislasi itu disusun dalam satu kesatuan sistem hukum pidana (kebijakan legislatif) yang harmonis dan terpadu. Untuk menyusun kebijakan kriminalisasi yang harmonis maka dibutuhkan harmonisasi materi/substansi tindak pidana baik yang bersifat eksternal (Internasional/global), tetapi juga kajian harmonisasi internal (Nasional). ${ }^{37}$

\section{Kebijakan Formulasi Pengaturan Tindak Pidana Teknologi Informasi Menurut KUHPidana.}

Kebijakan hukum pidana (tataran aplikatif) sangat dipengaruhi sistem hukum yang berlaku saat ini. Hukum pidana Indonesia yang ada saat ini dan pengembangan ke depan dipengaruhi oleh tradisi hukum civil law. Politik hukum yang cenderung mengarah pada tradisi civil law mengandung konsekuensi sebagai berikut:

a. Peraturan perundang-undangan harus dirumuskan secara teliti dan lengkap sehingga diharapkan mampu menjangkau semua permasalahan yang timbul.

b. Asas legalitas ditempatkan sebagai landasan yang bersifat fundamental dan dalam pelaksanaannya harus dijunjung tinggi tanpa kecuali.

c. Operasionalisasi peraturan perundang-undangan diupayakan seoptimal mungkin untuk menangani berbagai kasus yang bervariasi dengan pendekatan penafsiran (interpretasi).

36 Dokumen A/CONF.187/15, Report of the Tenth UN Congress, "Report of CommitteelI" mengenai "Workswhop on crimes related to the computer network",yang kemudian dimasukan dalam "Report of the Tenth United nations Congress on the preventation of crime and the Treatment of Offenders",paragraf 161-174, hal. 25- 27. Lihat dalam Barda Nawawi Arief, Masalah Penegakan Hukum dan Kebijakan Hukum Pidana dalam Penanggulangan Kejahatan, Op.Cit, hal. 241-242.

37 Barda Nawawi Arief, Kapita Selekta Hukum Pidana, Op.Cit, hal. 259-260. 
Instrumen hukum memberikan landasan atau pedoman bagi para penegak hukum yang akan diterapkan kepada para pelaku cybercrime. Sebagai hukum positif, pembuatannya tentu melalui mekanisme pembuatan perundang-undangan dan sekaligus melekat sifat ius constitutum, yakni menjadi hukum positif yang memberikan sanksi bagi peristiwa atau perbuatan kriminal yang menggunakan komputer.

Sebelum UU ITE diterbitkan terdapat ketentuan hukum positif yang dapat diterapkan untuk melakukan terobosan dengan penafsiran hukum yang berkaitan dengan teknologi informasi khususnya kejahatan yang berkaitan dengan internet (cyber crime). Metode penafsiran hukum yang dilakukan oleh aparat penegak hukum menjadi hal yang logis untuk menghindari kekosongan hukum terhadap tindak pidana teknologi informasi. Penerapan ketentuan-ketentuan hukum positif sebelum adanya UU ITE tidaklah sederhana karena karateristik cybercrime yang bersifat khas dari kejahatan konvensional/ di dunia biasa. Sebenarnya di Indonesia dalam persoalan cybercrime sebelum UU ITE diterbitkan tidak ada kekosongan hukum, ini terjadi jika digunakan metode penafsiran yang dikenal dalam ilmu hukum dan hal ini yang mestinya dipegang oleh aparat penegak hukum dalam menghadapi perbuatanperbuatan berdimensi baru yang secara khusus belum diatur dalam undangundang. ${ }^{38}$
Kitab Undang-Undang Hukum Pidana (KUHPidana) yang berlaku sekarang ini berasal dari Wetboek van Strafrecht voor Nederlandsh Indie (WvSNI) dengan berbagai perubahan untuk disesuaikan dengan keadaan di Indonesia (Hindia Belanda) saat itu. Sebagai sumber hukum pidana disamping sumber-sumber lainnya, KUHPidana menduduki posisi yang amat penting, hal ini karena KUHPidana memuat asas-asas hukum pidana yang dapat dilihat pada Buku Ke-satu mengenai aturan umum. sistem peraturan perundangundangan (statutory rules) yang ada di dalam KUHPidana sebagai induk aturan umum sehingga undang-undang khusus di luar KUHPidana terikat kepada ketentuan umum yang ada di dalam KUHPidana (Buku 1).

KUHPidana terbagi atas aturan umum yang terdapat di dalam KUHPidana (Buku I), dan aturan khusus terdapat di dalam KUHPidana (Buku II dan III). Namun ketentuan umum KUHPidana yang mengikat (berlaku) untuk undang-undang khusus, hanyalah Bab I s/d VIII (Pasal 1 s/d 85) Buku I KUHPidana, sepanjang undang-undang khusus tidak membuat ketentuan lain yang menyimpang (Lihat Pasal 103 KUHPidana). Ketentuan umum dalam Bab IX Buku I KUHP (Pasal 86 s/d 102) hanya berlaku untuk KUHPidana, tidak untuk undang-undang khusus di luar KUHPidana. Sampai dengan saat ini, KUHPidana belum dilakukan perubahan dan penambahan terhadap tindak pidana yang berhubungan dengan dunia mayantara (virtual) terutama yang

38 Badan Pembinaan Hukum Nasional, Perkembangan Pembangunan Hukum Nasional tentang Hukum Teknologi dan Informasi, BPHN Departemen Kehakiman RI, 1995/1996, hlm. 32-34. 
berhubungan dengan penyalahgunaan internet, alat bukti elektronik, yurisdiksi dan sebagainya.

Upaya menangani kasus kejahatan dunia maya, terdapat beberapa pasal dalam KUHPidana yang mengkriminalisasi cybercrime dengan menggunakan metode interpretasi ekstensif (perumpamaan dan persamaan) terhadap pasal-pasal yang terdapat dalam KUHPidana. Adapun pasal-pasal yang dapat dikenakan dalam KUHPidana yang mengkriminalisasi terhadap kejahatan dunia mayantara, sebagaimana dikatakan oleh Petrus Reinhard Golose di antaranya adalah: ${ }^{39}$

a. Pasal 362, untuk kasus Carding dimana pelaku mencuri kartu kredit milik orang lain walaupun tidak secara fisik karena hanya nomor kartunya saja yang diambil dengan menggunakan software card generator di internet untuk melakukan transaksi di e-commerce.

b. Pasal 378, untuk penipuan dengan seolah-olah menawarkan dan menjual suatu produk atau barang dengan memasang iklan di salah satu website sehingga orang tertarik untuk membelinya lalu mengirimkan uang kepada pemasang iklan.

c. Pasal 335, dapat dikenakan untuk kasus pengancaman dan pemerasan yang dilakukan melalui $e$-mail.

d. Pasal 331, dapat dikenakan untuk kasus pencemaran nama baik dengan menggunakan media internet. Modusnya adalah pelaku menyebarkan e-mail kepada teman-teman korban tentang suatu cerita yang tidak benar atau mengirimkan e-mail secara berantai melalui mailling list (millis) tentang berita yang tidak benar.

e. Pasal 303, dapat dikenakan untuk menjerat permainan judi yang dilakukan secara on-line di internet dengan penyelenggara dari Indonesia.

f. Pasal 282, dapat dikenakan untuk penyebaran pornografi maupun website porno yang banyak beredar dan mudah diakses di internet.

g. Pasal 282 dan 311, dapat dikenakan untuk penyebaran foto atau film pribadi seseorang yang vulgar di internet.

h. Pasal 378 dan 262, dapat dikenakan pada kasus carding, karena pelaku melakukan penipuan seolah-olah ingin membeli suatu barang dan membayar dengan kartu kredit yang nomor kartu kreditnya merupakan hasil curian.

i. Pasal 406, dapat dikenakan pada kasus deface suatu website, karena pelaku setelah berhasil memasuki website korban, selanjutnya melakukan pengrusakan dengan cara mengganti tampilan asli dari website tersebut.

Penerapan pasal-pasal KUHPidana yang dijelaskan di atas, sudah tidak relevan dalam penanggulangan tindak pidana teknologi informasi. Salah satu contohnya adalah terhadap dalam penerapan unsur-unsur pasal, rumusan pasal-pasal tersebut tidak disebutkan unsur-unsur mengenai data komputer

39 Petrus Reinhard Golose, Perkembangan Cybercrime dan Upaya Penanggulangannya di Indonesia Oleh Polri, Buletin Hukum Perbankan dan Kebanksentralan Volume 4 Nomor 2, Jakarta, Agustus 2006, hlm. 38-39. 
atau informasi yang dihasilkan komputer sebagai alat bukti elektronik baik sebagai media seperti disket, tape storage, disk storage, compact disk, hard disk, USB, flash disk dan hasil cetakan bukti elektronik tersebut. KUHPidana sampai saat ini belum melakukan perubahan dan penambahan terhadap tindak pidana yang berhubungan dengan mayantara terutama yang berhubungan dengan penyalahgunaan internet, alat bukti elektronik, yurisdiksi dan sebagainya.

\section{Formulasi Hukum Tindak Pidana Penipuan Transaksi Elektronik}

Pemerintah Indonesia telah membuat kebijakanyangberhubungandenganhukum teknologi informasi (law of information technology) dengan diterbitkannya UU ITE pada tanggal 21 April 2008 oleh Menteri Hukum dan Hak Asasi Manusia. Produk hukum yang berkaitan dengan ruang siber (cyber space) atau mayantara ini dianggap oleh pemerintah perlu untuk memberikan keamanan dan kepastian hukum dalam pemanfaatan teknologi informasi, media, dan komunikasi agar dapat berkembang secara optimal.

UU ITE tidak secara khusus mengatur mengenai tindak pidana penipuan. Selama ini, tindak pidana penipuan berdiri sendiri diatur dalam Pasal 378 KUHPidana, dengan rumusan pasal sebagai berikut:

"Barangsiapa dengan maksud untuk menguntungkan diri sendiri atau orang lain secara melawan hukum dengan menggunakan nama palsu atau martabat (hoedaningheid) palsu; dengan tipu muslihat, ataupun rangkaian kebohongan, menggerakkan orang lain untuk menyerahkan barang sesuatu kepadanya, atau supaya memberi utang maupun menghapuskan piutang, diancam, karena penipuan, dengan pidana penjara paling lama empat tahun."

Unsur-unsur Pasal 378 KUHPidana, sebagai berikut: ${ }^{40}$

a. Barangsiapa menunjukkan bahwa siapapun yang melakukan perbuatan;

b. Membujuk, melakukan pengaruh dengan kelicikan terhadap orang, sehingga orang itu menurutinya berbuat sesuatu yang apabila mengetahui duduk perkara yang sebenarnya, ia tidak akan berbuat demikian; Membujuk orang supaya memberikan barang, membuat utang atau menghapuskan piutang;

c. Barang, segala sesuatu yang berwujud, termasuk uang;

d. Denganmaksuduntukmenguntungkan diri sendiri atau orang lain dengan cara melawan hukum; Menguntungkan diri sendiri dengan melawan hak, menguntungkan diri sendiri dengan tidak berhak;

e. Dengan menggunakan nama atau keadaan palsu, akal cerdik (tipu muslihat) atau karangan perkataan bohong; Nama palsu, nama yang bukan nama sendiri; Keadaan palsu, misalnya mengaku dan bertindak sebagai agen polisi, notaris, pastor, bank, yang sebenarnya ia bukan penjabat itu;

40 R. Soesilo, KUHP serta Komentar-Komentarnya Lengkap Pasal Demi Pasal, Politeia, Bogor, 1993, hlm. 261. 
f. Akal cerdik atau tipu muslihat, suatu tipu yang demikian liciknya, sehingga seorang yang berpikiran normal dapat tertipu.

Walaupun UU ITE tidak secara khusus mengatur mengenai tindak pidana penipuan, namun terkait dengan timbulnya kerugian konsumen dalam transaksi elektronik terdapat ketentuan Pasal 28 ayat (1) UU ITE yang menyatakan:

"Setiap Orang dengan sengaja, dan tanpa hak menyebarkan berita bohong dan menyesatkan yang mengakibatkan kerugian konsumen dalam Transaksi Elektronik."

Terhadap pelanggaran Pasal 28 ayat (1) UU ITE diancam pidana penjara paling lama enam tahun dan/atau denda paling banyak Rp 1 miliar, sesuai pengaturan Pasal 45 ayat (2) UU ITE. Dari rumusanrumusan Pasal 28 ayat (1) UU ITE dan Pasal 378 KUHPidana tersebut, dapat kita ketahui bahwa keduanya mengatur hal yang berbeda. Pasal 378 KUHPidana mengatur penipuan, sementara Pasal 28 ayat (1) UU ITE mengatur mengenai berita bohong yang menyebabkan kerugian konsumen dalam transaksi elektronik. Perbuatan yang diatur dalam Pasal 28 ayat (1) UU ITE merupakan salah satu perbuatan yang dilarang dalam UU ITE, walaupun UU ITE sendiri tidak menjelaskan apa yang dimaksud dengan berita bohong dan menyesatkan.

Terkait dengan rumusan Pasal 28 ayat (1) UU ITE yang menggunakan frasa menyebarkan berita bohong, sebenarnya terdapat ketentuan serupa dalam Pasal
390 KUHPidana) walaupun dengan rumusan yang sedikit berbeda yaitu digunakannya frasa menyiarkan kabar bohong. Menurut R. Soesilo, terdakwa hanya dapat dihukum dengan Pasal 390 KUHPidana, apabila ternyata bahwa kabar yang disiarkan itu adalah kabar bohong. ${ }^{41}$ Yang dipandang sebagai kabar bohong, tidak saja memberitahukan suatu kabar yang kosong, akan tetapi juga menceritakan secara tidak betul tentang suatu kejadian. Penjelasan ini berlaku juga bagi Pasal 28 ayat (1) UU ITE, bahwa suatu berita yang menceritakan secara tidak betul tentang suatu kejadian dalam transaksi elektronik adalah termasuk juga berita bohong. Kalimat bohong dan menyesatkan adalah dua hal yang berbeda, frasa menyebarkan berita bohong yang diatur adalah perbuatannya, sedangkan dalam kata menyesatkan yang diatur adalah akibatnya. Berita bohong dapat diartikan tidak sesuai dengan hal/keadaan yang sebenarnya dan menyesatkan dapat diartikan menyebabkan seseorang berpandangan pemikiran salah/keliru.

Untuk membuktikan telah terjadi pelanggaran terhadap Pasal 28 ayat (1) UU ITE, maka harus terpenuhi dahulu semua unsur dari pasal tersebut, unsur-unsur tersebut yaitu:

a. Setiap orang.

b. Dengan sengaja dan tanpa hak. Bahwa unsur dengan sengaja dan tanpa hak merupakan satu kesatuan dalam tataran penerapan hukum yang harus dapat dibuktikan oleh aparat penegak hukum. Unsur dengan sengaja dan tanpa hak mengartikan pelaku 
menghendaki dan mengetahui secara sadar bahwa tindakannya dilakukan tanpa hak. Pada umumnya merupakan bagian dari perbuatan melawan hukum yaitu setiap perbuatan yang melanggar hukum tertulis (peraturan perundang-undangan) dan atau asasasas hukum umum dari hukum tidak tertulis.

c. Menyebarkan berita bohong dan menyesatkan. Karena rumusan unsur menggunakan kata "dan", artinya kedua unsurnya harus terpenuhi untuk pemidanaan. yaitu menyebarkan berita bohong (tidak sesuai dengan hal/keadaan yang sebenarnya) dan menyesatkan (menyebabkan seseorang berpandangan pemikiran salah/keliru). Apabila berita bohong tersebut tidak menyebabkan seseorang berpandangan salah, maka tidak dapat dilakukan pemidanaan.

d. Yang mengakibatkan kerugian kepada orang dalam melakukan kegiatan transaksi elektronik. Unsur yang terakhir ini mensyaratkan berita bohong dan menyesatkan tersebut harus mengakibatkan suatu kerugian kepada seseorang. Artinya, tidak dapat dilakukan pemidanaan, apabila tidak menyebabkan kerugian kepada seseorang di dalam kegiatan transaksi elektronik tersebut.

Walaupun begitu, kedua tindak pidana tersebut memiliki suatu kesamaan, yaitu dapat mengakibatkan kerugian bagi orang lain. Tapi, rumusan Pasal 28 ayat (1) UU ITE tidak mensyaratkan adanya unsur menguntungkan diri sendiri atau orang lain sebagaimana diatur dalam Pasal 378 KUHPidana tentang penipuan. Pada akhirnya, yang dibutuhkan adalah kejelian pihak penyidik kepolisian untuk menentukan kapan harus menggunakan Pasal 378 KUHPidana dan kapan harus menggunakan ketentuan-ketentuan dalam Pasal 28 ayat (1) UU ITE.

Pada praktiknya pihak kepolisian dapat mengenakan pasal-pasal berlapis terhadap suatu tindak pidana yang memenuhi unsur-unsur tindak pidana penipuan sebagaimana diatur dalam Pasal 378 KUHPidana dan memenuhi unsurunsur tindak pidana Pasal 28 ayat (1) UU ITE. Artinya, bila memang unsur-unsur tindak pidananya terpenuhi, polisi dapat menggunakan kedua pasal tersebut yang disesuaikan dengan fungsi dan tujuan hukum pidana. Fungsi dan tujuan hukum pidana dijelaskan oleh Tongat sebagai

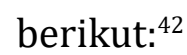

Secara khusus, hukum pidana berfungsi melindungi kepentingan hukum (nyawa, badan, kehormatan, harta dan kemerdekaan) dari perbuatan yang akan menyerangnya/merusaknya dengan sanksinya berupa pidana yang sifatnya tegas dibandingkan sanksi yang terdapat dalam bidang hukum lain.

Menurut Tongat, ketentuan-ketentuan di atas sejalan dengan asas nullum delictum noela poena sine pravia lege poenali (tidak ada pidana tanpa peraturan lebih dahulu) atau biasanya asas ini disebut asas

42 Tongat, Dasar-Dasar Hukum Pidana Indonesia dalam Perspektif Pembaharuan, UMM Pres, Malang, 2008, hlm. 22. 
legalitas". ${ }^{43}$ Sanksi pidana yang terdapat di dalam seluruh ketentuan sebagaimana disebutkan di atas pada dasarnya hanya dikenakan kepada pelaku atau pembuat yang melanggar ketentuan undang-undang tersebut. Menurut Sudarto, hal ini dalam hukum pidana dikenal dengan asas tiada pidana tanpa kesalahan (keine strafe ohne schuld atau geen staf zonder schuld atau nulla poena sine culpa). ${ }^{44}$ Asas ini menurut Sudarto, tidak tercantum dalam KUHP, tetapi berlakunya asas ini tidak diragukan, karena akan bertentangan dengan rasa keadilan, apabila ada orang yang dijatuhi pidana padahal orang tersebut sama sekali tidak bersalah. ${ }^{45}$

Asas lain yang paling penting dalam hubungannya dengan tindak pidana penipuan transaksi elektronik, adalah asas praduga tidak bersalah, sebagaimana penjelasan umum KUHAP butir (3) huruf c, yang menerangkan bahwa:

Setiap orang yang disangka, ditangkap, ditahan, dituntut dan atau dihadapkan di muka sidang pengadilan, wajib dianggap tidak bersalah sampai adanya putusan pengadilan yang menyatakan kesalahannya dan memperoleh kekuatan hukum tetap".

Menurut M. Yahya Harahap, mengenai asas praduga tidak bersalah, tersangka harus ditempatkan pada kedudukan manusia yang memiliki hakikat martabat. Dia harus dinilai sebagai subjek, bukan objek, yang diperiksa bukan manusia tersangka. Perbuatan tindak pidana yang dilakukan, yang menjadi objek pemeriksaan. Ke arah kesalahan tindak pidana yang dilakukan pemeriksaan ditujukan. Tersangka harus dianggap tidak bersalah, sesuai dengan asas praduga tidak bersalah, sampai diperoleh putusan pengadilan yang telah berkekuatan tetap. ${ }^{46}$

Penegakan hukumterhadap ketentuanketentuan di atas harus dilaksanakan tanpa pandang bulu, sebagai bentuk keyakinan atas doktrin hukum, bahwa setiap orang mempunyai kedudukan yang sama di depan hukum (equality before the law). Akan tetapi, keadaan sesungguhnya tidak sesederhana itu. Efektivitas penegakan hukum dalam sistem hukum suatu negara dipengaruhi oleh beberapa faktor. Seluruh norma-norma hukum yang disebutkan di atas khususnya dan norma-norma hukum umumnya dalam berfungsinya, menurut Soerjono Soekanto sangatlah tergantung pada hubungan yang serasi antara hukum itu sendiri, penegak hukum, fasilitasnya dan masyarakat yang diaturnya. ${ }^{47}$

Menurut Soerjono Soekanto, faktorfaktor yang mempengaruhi dalam menentukan berlakunya hukum itu adalah:

a. Faktor hukumnya sendiri;

b. Faktor penegak hukumnya, yakni pihak-pihak yang membentuk maupun yang menerapkan hukum;

43 Andi Hamzah, Asas-asas Hukum Pidana, Rineka Cipta, 2007, hlm. 39.

44 Sudarto, Hukum Pidana I, Cetakan ke II, Yayasan Sudarto, Fakultas Hukum UNDIP, Semarang, 1990, hlm. 85.

45 Idem.

46 M. Yahya Harahap, Pembahasan Permasalahan dan Penerapan KUHAP Penyidikan dan Penuntutan, Sinar Grafika, Jakarta, 2006, hlm. 34.

47 Soerjono Soekanto, Sosiologi Hukum dalam Masyarakat, Rajawali Pers, Jakarta, 1987, hlm. 20. 
c. Faktor sarana atau fasilitas yang mendukung penegakan hukum;

d. Faktor masyarakat, yakni lingkungan dimana hukum tersebut berlaku atau diterapkan;

e. Faktor kebudayaan, yakni sebagai hasil karya, cipta dan rasa yang didasarkan pada karsa manusia di dalam pergaulan hidup. ${ }^{48}$

Kejahatan penipuan menggunakan transaksi elektronik pada prinsipnya sama dengan penipuan secara konvensional atau penipuan yang terjadi di dalam masyarakat. Hal yang membedakan hanyalah pada sarana perbuatannya yakni menggunakan sistem elektronik atau dengan menggunakan sarana komputer yang terhubung langsung ke dalam jaringan internet. Sehingga secara hukum, penipuan dengan menggunakan transaksi elektronik dapat diperlakukan sama sebagaimana penipuan yang terjadi secara konvensional dan dapat dijerat dengan aturan hukum yang terdapat dalam Undang-undang Nomor 11 Tahun 2008 tentang Informasi dan Transaksi Elektronik Jo KUH Pidana.

\section{Kendala Dalam Menanggulangi Kejahatan Penipuan Transaksi Elektronik}

Penanggulangan kejahatan di dunia maya tidak terlepas dari kebijakan penanggulangan kejahatan atau yang biasa dikenal dengan istilah politik kriminal, menurut Sudarto politik kriminal merupakan suatu usaha yang rasional dari masyarakat dalam menanggulangi kejahatan. ${ }^{49}$ Oleh karena itu tujuan pembuatan UU ITE tidak terlepas dari tujuan politik kriminal yaitu sebagai upaya untuk kesejahteraan sosial (social welfare) dan untuk perlindungan masyarakat (social defence). Evaluasi terhadap kebijakan di dunia mayantara tetap diperlukan sekiranya ada kelemahan kebijakan formulasi dalam perundang-undangan tersebut. Menurut Barda Nawawi Arief, evaluasi atau kajian ulang ini perlu dilakukan, karena ada keterkaitan erat antara kebijakan formulasi perundang-undangan (legaslative policy) dengan kebijakan penegakan hukum (law enforcement policy) dan kebijakan pemberantasan/ penanggulangan kejahatan (criminal policy). Kelemahan kebijakan formulasi hukum pidana, akan berpengaruh pada kebijakan penegakan hukum pidana dan kebijakan penanggulangan kejahatan. ${ }^{50}$

Penegak hukum di Indonesia saat ini, mengalami kesulitan dalam menghadapi merebaknya cybercrime. Hal ini dilatarbelakangi masih sedikitnya aparat penegak hukum yang memahami seluk beluk teknologi informasi (internet), terbatasnya sarana dan prasarana, serta kurangnya kesadaran hukum masyarakat dalam dalam upaya penanggulangan tindak pidana teknologi informasi. Disamping itu aparat penegak hukum di daerah pun belum siap dalam mengantisipasi

\footnotetext{
48 Soerjono Soekanto, Faktor-Faktor Yang Mempengaruhi Penegakan Hukum, RajaGrafindo Persada, Jakarta, 2005, hlm. 5.

49 Sudarto, Hukum dan Hukum Pidana..., Op.Cit., hlm. 38.

50 Barda Nawawi Arief, Masalah Penegakan Hukum dan Kebijakan Hukum Pidana dalam Penanggulangan Kejahatan, Jakarta, 2007, hlm. 214-215.
} 
maraknya kejahatan ini karena masih banyak aparat penegak hukum yang gagap teknologi (gaptek) hal ini disebabkan oleh masih banyaknya institusi-institusi penegak hukum di daerah yang belum didukung dengan jaringan internet. Keterbatasan alat-alat khusus cyber crime yang dimiliki oleh Polisi di daerahdaerah kabupaten sampai dengan tingkat kecamatan untuk menunjang sarana prasarana penyidik dalam mengungkap tindak pidana penipuan transaksi elektronik. Keterbatasan alat-alat modern di daerah menyebabkan waktu cukup lama dalam mengungkap tindak kejahatan penipuan transaksi elektronik dan alatalat yang dibutuhkan juga memerlukan biaya yang besar.

Upaya untuk mengungkap dan menanggulangi kejahatan penipuan dengan menggunakan transaksi elektronik ini tidaklah mudah, selain karena kurangnya pemahaman atau kewaspadaan masyarakat terhadap tindak pidana penipuan melalui teknologi informasi, masyarakat lebih melihat nominal atau besaran jumlah keuntungan dari suatu barang yang ditawarkan. Ketika terjadi kerugian yang diakibatkan adanya penipuan transaksi elektronik, masyarakatpun dihadapkan dengan tidak mau melaporkan tindak kejahatan yang dialaminya ke aparat penegak hukum, karena: ${ }^{51}$

a. Masyarakat tidak percaya dengan kinerja aparat penegak hukumnya. b. Kekhawatiran masyarakat jika berurusan dengan aparat penegak hukum masyarakat akan semakin merugi. Ibarat kehilangan ayam, maka masyarakat harus siap kehilangan kambing, artinya sudah kehilangan harta bendanya masyarakat khawatir dipungut biaya oleh aparat penegak hukum.

c. Masyarakat khawatir keselamatan jiwanya terancam jika melaporkan tindak kejahatan yang dialaminya.

Pada umumnya suatu masyarakat yang mengalami perubahan sosial akibat kemajuan teknologi, banyak melahirkan masalah-masalah sosial. Hal itu terjadi karena kondisi masyarakat itu sendiri yang belum siap menerima perubahan atau dapat pula karena nilai-nilai masyarakat yang telah berubah dalam menilai kondisi yang tidak lagi dapat diterima. ${ }^{52}$ Memang tidak bisa diingkari oleh siapapun, bahwa teknologi itu dapat menjadi alat perubahan di tengah masyarakat. Demikian pentingnya fungsi teknologi, hingga sepertinya masyarakat dewasa ini sangat tergantung dengan teknologi, baik untuk hal-hal positif maupun negatif. Pada perkembangannya internet juga membawa sisi negatif, dengan membuka peluang munculnya tindakan-tindakan anti sosial yang selama ini dianggap tidak mungkin terjadi atau tidak akan terpikirkan terjadi. Sebuah teori menyatakan bahwa crime is product of society it self, yang secara sederhana dapat diartikan bahwa semakin tinggi tingkat intelektualitas suatu

51 J.E.Sahetapy, Kapita Selekta Kriminologi, Citra Adtya Bakti, Bandung, 1979, hlm. 49.

52 Horton, Paul B dan Chester L. Hunt, Sosiologi, Erlangga, Jakarta, 1984, hlm. 237. 
masyarakat, maka akan semakin canggih dan beraneka-ragam pulalah tingkat kejahatan yang dapat terjadi..$^{53}$

Untuk menangani kasus-kasus cybercrime khususnya tindak pidana penipuan transaksi elektronik, Indonesia sangat membutuhkan aparat penegak hukum yang mumpuni, yang terorganisasi dan terstruktur untuk menyatukan komunitas-komunitas spesialisasi dalam penanganan segala jenis tindak pidana cyber. Tanpa adanya penegakan hukum yang terorganisasi dan terstruktur di bidang teknologi informasi, maka akan sulit menjerat penjahat-penjahat cyber oleh karena kejahatan cyber ini locos delicti-nya bisa lintas negara. Dalam hal menangani kasus cybercrime khususnya tindak pidana penipuan transaksi elektronik diperlukan spesialisasi aparat penyidik yang dapat dipertimbangkan sebagai salah satu cara untuk melaksanakan upaya penegakan hukum terhadap cybercrime. Spesialisasi tersebut dimulai dari adanya pendidikan yang diarahkan untuk menguasai teknis serta dasar-dasar pengetahuan di bidang teknologi komputer. Pasal 43 UU ITE, menerangkan selain Penyidik Pejabat Polisi Negara Republik Indonesia, Pejabat Pegawai Negeri Sipil tertentu dilingkungan Pemerintah yang lingkup tugas dan tanggung jawabnya di bidang Teknologi Informasi dan Transaksi Elektronik diberi wewenang khusus sebagai penyidik sebagaimana dimaksud dalam UndangUndang tentang Hukum Acara Pidana untuk melakukan penyidikan tindak pidana di bidang Teknologi Informasi dan Transaksi Elektronik.

Bagaimana bisa melaksanakan tugas dan tanggung jawabnya sebagai penyidik di bidang teknologi informasi dan transaksi elektronik, apabila tanpa adanya sarana atau fasilitas tertentu, maka tidak mungkin penegakan hukum akan berlangsung dengan lancar. Sarana atau fasilitas tersebut antara lain, mencakup tenaga manusia yang berpendidikan dan trampil, organisasi yang baik, peralatan yang memadai, keuangan yang cukup, dan seterusnya. Menurut Strecher (1971:5966) penegakan hukum bukanlah suatu yang bisa dilihat sebagai berdiri sendiri, melainkan senantiasa bertukar kegiatan dengan masyarakat yang melayaninya, atau yang dengan mengutip Parsons kita sebut sebagai relational. Dengan demikian kiranya bila diterima, bahwa perubahanperubahan dalam masyarakat yang disebabkan oleh penggunaan teknologi modern, terutama yang berupa peliputan dalam kecepatan dan daya merusak, akan memberikan pengaruhnya sendiri terhadap penegakan hukum dalam masyarakat. Khususnya dalam hubungan dengan pekerjaan penegakan hukum yang dalam hal ini banyak dipusatkan pada pekerjaan kepolisian. ${ }^{54}$ Penegakan hukum merupakan suatu usaha untuk mewujudkan ide-ide tentang kepastian hukum, kemanfaatan sosial dan keadilan menjadi kenyataan. Proses perwujudan

\footnotetext{
53 Abdul Wahib dan Mohammad Labib, Kejahatan Mayantara (Cybercrime), Abdul Wahib dan Mohammad Labib, Kejahatan Mayantara (Cybercrime), Kejahatan Mayantara (Cybercrime), Refika Aditama, Bandung, 2005, hlm. 39.

54 Satjipto Rahardjo, Masalah Penegakan Hukum Suatu Tinjauan Sosiologis, Sinar Baru, Bandung, 2005, hlm. 125-126.
} 
ide-ide itulah yang merupakan hakikat dari penegakan hukum. ${ }^{55}$

\section{PENUTUP}

Terhadap kendala dalam menanggulangi tindak pidana penipuan transaksi elektronik di Indonesia karena terbatasnya sarana dan prasarana, serta kurangnya kesadaran hukum masyarakat, seyogyanya aparat penegakan hukum membutuhkan sinergi antara masyarakat yang partisipatif dengan aparat penegak hukum yang demokratis, transparan, bertanggung jawab dan berorientasi pada pengayoman sebenarnya. Kepolisian sebagai aparat penegak hukum, juga memerlukan kerja sama yang melibatkan sivitas akademika diperguruan tinggi ilmu hukum, untuk dapat memberikan penyuluhan-penyuluhan berkelanjutan kepada masyarakat tentang dampak bertransaksi elektronik, bagaimana mencegah atau menanggulangi tindak pidana penipuan transaksi elektronik dan sosialisasi bijak dalam menggunakan teknologi informasi dan komunikasi, dengan tidak melanggar undang-undang, tidak bertentangan dengan kesusilaan dan kepatutan.

Pada akhirnya perangkat hukum yang sudah ada, diharapkan tidak berorientasi pada apa yang seharusnya (das sollen), tetapi harus memperhatikan apa yang senyatanya (dassein), akomodatif terhadap perkembangan serta antisipatif terhadap permasalahan, termasuk dampak negatif penyalahgunaan internet dengan berbagai motivasi yang dapat menimbulkan korban-korban seperti kerugian materi dan non-materi, juga sebagai upaya terpenuhinya rasa aman di masyarakat yang dengan sendirinya akan membangun suasana kondusif, menciptakan kondisi stabilitas pembangunan masyarakat yang berkelanjutan, adil, makmur dan sejahtera, berdasarkan keimanan dan ketaqwaan kepada Ilahi Robby, Tuhan yang Maha Esa, baldatun thoyyibatun warabbun ghofur.

\section{DAFTAR PUSTAKA}

\section{Buku}

A Mukhtie Fadjar, Tipe Negara Hukum, Banyumedia, Malang, 2005.

$\mathrm{Az}$ Nasution, Hukum Perlindungan Konsumen (Suatu Pengantar), Diadit Media, Jakarta, 2002.

Abdul Wahib dan Mohammad Labib, Kejahatan Mayantara (Cybercrime), Abdul Wahib dan Mohammad Labib, Kejahatan Mayantara (Cybercrime), Kejahatan Mayantara (Cybercrime), Refika Aditama, Bandung, 2005.

Agus Raharjo, Cybercrime Pemahaman dan Upaya Pencegahan Kejahatan Berteknologi, Citra Aditya Bakti, Bandung, 2002.

Andi Hamzah, Asas-asas Hukum Pidana, Rineka Cipta, 2007.

Ahmad M Ramli, Cyber Law dan HAKI dalam Sistem Hukum Indonesia, Refika Aditama, Bandung, 2004.

55 Satjipto Rahardjo, Masalah Penegakan Hukum, Alumni, Bandung, 1987, hlm. 15. 
Badan Pembinaan Hukum Nasional,

Perkembangan Pembangunan Hukum Nasional tentang Hukum Teknologi dan Informasi, BPHN Departemen Kehakiman RI, 1995/1996.

Barda Nawawi Arief, Masalah Penegakan Hukum dan Kebijakan Hukum Pidana dalam Penanggulangan Kejahatan, Jakarta, 2007.

, Pembaharuan Hukum Pidana

Dalam Perspektif Kajian Perbandingan, Citra Aditya Bakti, Bandung, 2005.

$\longrightarrow$ Tindak Pidana Mayantara, Perkembangan Kajian Cybercrime di Indonesia, RajaGrafindo Persada, Jakarta, 2006.

\section{$\longrightarrow$ Tindak Pidana Mayantara, Perkembangan Kajian Cybercrime di Indonesia, Raja Grafindo Persada, Jakarta, 2006.}

Didik J Rachbini, Mitos dan Implikasi Globalisasi: Catatan Untuk Bidang Ekonomi dan Keuangan, Pengantar edisi Indonesia dalam Hirst, Paul dan Grahame Thompson, Globalisasi adalah Mitos, Yayasan Obor, Jakarta, 2001.

Edi Suharto, Kebijakan Sosial sebagai Kebijakan Publik: Peranan Pembangunan Kesejahteraan Sosialdan Pekerjaan Sosial dalam Mewujudkan Negara Kesejahteraan (Welfare State) di Indonesia, Alfabeta, Bandung, 2008.

Horton, Paul B dan Chester L.Hunt, Sosiologi, Erlangga, Jakarta, 1984.
J.E.Sahetapy, Kapita Selekta Kriminologi, Citra Adtya Bakti, Bandung, 1979.

Juhaya S. Praja, Filsafat Hukum Islam, Lathifah Press bekerjasama dengan Fakultas Syari'ah IAILM Suryalaya, Tasikmalaya, 2004.

M. Arief Amarullah, Politik Hukum Pidana dalam Perlindungan Korban Kejahatan Ekonomi di Bidang Perbankan, Banyumedia, Malang, 2007.

M. Yahya Harahap, Pembahasan Permasalahan dan Penerapan KUHAP Penyidikan dan Penuntutan, Sinar Grafika, Jakarta, 2006.

Muchsin, Perlindungan dan Kepastian Hukum bagi Investor di Indonesia, Magister Ilmu Hukum Program Pascasarjana, Surakarta, 2003.

Mochtar Kusumaatmadja, Fungsi dan Perkembangan Hukum dalam Pembangunan Nasional, Binacipta, Bandung, Tanpa Tahun. , Hukum, Masyarakat dan Pembinaan Hukum Nasional, Binacipta, Bandung, 1976. , Konsep-konsep Hukum dalam Pembangunan, Alumni, Bandung, 2002.

Ni'matul Huda, Negara Hukum, Demokrasi \&Judicial Review, UII Press, Yogyakarta, 2005. 
Padmo Wahjono, Indonesia Negara Berdasarkan atas Hukum, Ghalia Indonesia, Jakarta, 1986.

Petrus Reinhard Golose, Perkembangan Cybercrime dan Upaya Penanggulangannya di Indonesia Oleh Polri, Buletin Hukum Perbankan dan Kebanksentralan Volume 4 Nomor 2, Jakarta, Agustus 2006.

Philipus M. Hadjon, Perlindungan Hukum Bagi Rakyat Indonesia, Bina Ilmu, Surabaya, 1987.

R. Soesilo, KUHP serta KomentarKomentarnya Lengkap Pasal Demi Pasal, Politeia, Bogor, 1993.

Satjipto Rahardjo, Permasalahan Hukum di Indonesia, Alumni, Bandung, 1983.

__ Masalah Penegakan Hukum, Alumni, Bandung, 1987. , Masalah Penegakan Hukum Suatu Tinjauan Sosiologis, Sinar Baru, Bandung, 2005.

Satjipto Rahardjo, Membedah Hukum Progresif, Kompas, Jakarta, 2007.

Sudarto, Hukum dan Hukum Pidana, Alumni, Bandung, 1977.

Hukum Pidana I, Cetakan ke II, Yayasan Sudarto, Fakultas Hukum UNDIP, Semarang, 1990.
Sutan Remy Syahdeni, Kejahatan dan Tindak Pidana Komputer, Pustaka Utama Grafiti, Jakarta, 2006.

Sutarman, Cybercrime: Modus Operandi dan Penanggulangannya, Laksbang Pressindo, Jogjakarta, 2007.

Soerjono Soekanto, Sosiologi Hukum dalam Masyarakat, Rajawali Pers, Jakarta, 1987.

_. Faktor-Faktor Yang Mempengaruhi Penegakan Hukum, Raja Grafindo Persada, Jakarta, 2005.

Tongat, Dasar-Dasar Hukum Pidana Indonesia dalam Perspektif Pembaharuan, UMM Pres, Malang, 2008.

Ujang Charda S., "Reaktualisasi Supremasi Hukum dalam Merekonstruksi Lembaga Peradilan Menuju Indonesia Baru", Jurnal Jurista Insentif'06, Vol. 1 No. 1, Kopertis Wilayah IV JabarBanten, Bandung, 2006.

Wagiati Soetedjo, Hukum Pidana Anak, Refika Aditama, Bandung, 2008.

Wigantoro Roes Setiyadi, Naskah akademik RUU tindak pidana di bidang Teknologi Informasi, CyberPolicy Club dan Indonesia Media Law and Policy Center, 2003. 


\section{Sumber Internet}

Agung Setya, Indonesia Urutan Kedua

Terbesar Negara Asal Cyber Crime di Dunia, http://nasional.kompas. com/read/2015/05/12/06551741/ Indonesia.urutan.kedua.terbesar. negara.asal.cyber.crime.di.dunia, diakses tanggal 15 Mei 2015, pukul 16.10 WIB.

Agung Setya, Awas!! Cyber Crime Modus Ini Paling Marak di Indonesia, http://www.jpnn.com/ $\mathrm{read} / 2015 / 12 / 20 / 345801 / a w a s ! !-$ cyber-crime-modus-ini-paling-marakdi-Indonesia, diakses tanggal 15 Mei 2015, pukul 16.20 WIB.

Hermawan, Subdit IV Cyber Crime Ungkap Penipuan Melalui Jejaring Sosial Facebook, http://www.reskrimsus. metro.polri.go.id/info/berita/ SUBDIT-IV-cyber-crime-ungkappenipuan-melalui-jejaring-sosialfacebook, diakses tanggal 30 Januari 2015, pukul 12:15 WIB.

Raypratama, Perlindungan Hukum, blogs pot.com/2015/04/teoriperlindungan-hukum.html, diakses tanggal 19 Juni 2015, pukul 15.00.WIB.

Ririn NF, Kejahatan Sering Manfaatkan Transaksi Elektronik, http://www. pikiran-rakyat.com/bandungraya/2015/01/28/313911/ kejahatan-sering-manfaatkantransaksi-elektronik, diakses tanggal 30 Januari 2015, pukul 11:15 WIB. 